\title{
Major Salivary Gland Non-Hodgkin Lymphoma
}

National Cancer Institute

\section{Source}

National Cancer Institute. Major Salivary Gland Non-Hodgkin Lymphoma. NCI Thesaurus.

Code C5981.

A non-Hodgkin lymphoma that arises from the parotid gland, submandibular gland, or sublingual gland. Representative examples include mucosa-associated lymphoid tissue lymphoma and diffuse large B-cell lymphoma. 